\title{
Herediter Tirozinemi Tip-1 ve Tip-1 Diabetes Mellitus Birlikteliğinde Diyet Yönetimi: Olgu Sunumu
}

\author{
Dietary Management in Coexistence of Hereditary Tyrosinemia Type-1 and Type-1 Diabetes \\ Mellitus: A Case Report
}

\section{Tuğçe Kartal ${ }^{1}$, Fatma Derya Bulut ${ }^{2}$, Deniz Kor ${ }^{3}$, Burcu Köşeci ${ }^{4}$, Can Celiloğlu ${ }^{5}$, Esra Kara ${ }^{6}$, Semine Özdemir Dilek ${ }^{7}$, Bilgin Yüksel ${ }^{8}$, Neslihan Önenli Mungan ${ }^{9}$}

Geliş tarihi/Received: 3.12.2021 • Kabul tarihi/Accepted: 29.12.2021

\section{ÖZET}

Herediter tirozinemi tip-1 (HT1), fumarilasetoasetat hidrolaz enzim eksikliğine bağll, nadir görülen hepatorenal bir kalıtsal metabolik hastalıktır. Herediter tirozinemi tip-1 yönetiminde, tirozin ve fenilalaninden kısıtlı diyetle birlikte nitisinon tedavisi kullanılması önerilmektedir. Otoimmün diyabet olarak da bilinen Tip-1 Diabetes Mellitus (T1DM), pankreas $\beta$-hücre disfonksiyonuna bağlı mutlak insülin eksikliği ile karakterize ve hiperglisemiye yol açan kronik endokrinolojik bir hastalıktır. Hastalarda glisemik kontrolü sağlamak için insülin ile birlikte beslenme tedavisi ve uygun fiziksel aktivite önemli yer tutmaktadır. Literatürde sınırlı sayıda olguda HT1 ve T1DM birlikteliği tanımlanmıştır. Bu sunumda tirozin metabolizma bozukluklarından HT1 nedeniyle izlenirken T1DM gelişen bir olgunun diyet yönetimi ve izlem süreci paylaşılmıştır. Yoğun insülin tedavisi ile fenilalanin ve tirozinden kısıtlı diyet tedavisi iki hastalık birlikteliğinde başarılı bir şekilde yönetilmiştir.

Anahtar kelimeler: Herediter tirozinemi tip-1, tip-1 diabetes mellitus, fenilalanin ve tirozinden kısitlı diyet, insülin tedavisi

\begin{abstract}
Hereditary tyrosinemia type-1 (HT1) is a rare hepatorenal inherited metabolic disease due to fumarilacetoacetate hydrolase enzyme deficiency. In the management of hereditary tyrosinemia type-1, it is recommended to use nitisinone therapy together with a tyrosine and phenylalanine restricted diet. Type-1 Diabetes Mellitus (T1DM), also known as autoimmune diabetes, is a chronic endocrinological disease characterized by absolute insulin deficiency due to pancreatic $\beta$-cell dysfunction and leading to hyperglycemia. In order to provide glycemic control in patients, nutritional therapy with insulin and appropriate physical activity have an important place. Coexistence of HT1 and T1DM has been described in a limited number of cases in the literature. In this paper, the diet management and follow-up process of a case who developed T1DM while being followed
\end{abstract}

1. İletişim/Correspondence: Çukurova Üniversitesi Tıp Fakültesi Pediatrik Metabolizma BD, Adana, Türkiye

E-posta: tugceozakcaoglu@gmail.com • io https://orcid.org/0000-0003-1498-3696

2. Çukurova Üniversitesi Tıp Fakültesi Pediatrik Metabolizma BD, Adana, Türkiye (1) https://orcid.org/0000-0003-0529-2404

3. Çukurova Üniversitesi Tıp Fakültesi Pediatrik Metabolizma BD, Adana, Türkiye (1) https://orcid.org/0000-0001-7659-0500

4. Çukurova Üniversitesi Tıp Fakültesi Pediatrik Metabolizma BD, Adana, Türkiye (1) https://orcid.org/0000-0002-0813-6776

5. Çukurova Üniversitesi Tıp Fakültesi Pediatrik Endokrinoloji BD, Adana, Türkiye (D) https://orcid.org/0000-0002-5163-421X
6. Çukurova Üniversitesi Tıp Fakültesi Pediatrik Metabolizma BD, Adana, Türkiye (D) https://orcid.org/0000-0001-9119-0791

7. Çukurova Üniversitesi Tıp Fakültesi Pediatrik Endokrinoloji BD, Adana, Türkiye (D) https://orcid.org/0000-0003-2100-0301

8. Çukurova Üniversitesi Tıp Fakültesi Pediatrik Endokrinoloji BD, Adana, Türkiye (1) https://orcid.org/0000-0003-4378-3255

9. Çukurova Üniversitesi Tıp Fakültesi Pediatrik Metabolizma BD, Adana, Türkiye (1) https://orcid.org/0000-0001-7862-3038 
up due to HT1, one of the tyrosine metabolism disorders, was shared. Intensive insulin therapy and phenylalanine and tyrosine-restricted diet therapy have been successfully managed in the comorbidity of the two diseases.

Keywords: Hereditary tyrosinemia type-1, type-1 diabetes mellitus, phenylalanine and tyrosine-restricted diet, insulin therapy

\section{GíRIŞ}

Herediter tirozinemi tip-1 (HT1), fumarilasetoasetat hidrolaz (FAH) enziminin eksikliğinden kaynaklanan kalıtsal bir tirozin metabolizması bozukluğudur $(1,2)$. FAH enzim eksikliği nedeniyle biriken toksik metabolitler, yaşamın erken dönemlerinde ciddi karaciğer fonksiyon bozukluğuna, renal tübülopatiye, porfiri benzeri nörolojik bulgulara, kardiyomiyopatiye, hepatosellüler karsinomaya (HCC) ve pankreatik adacık hiperplazisine bağlı hiperinsülinemik hipoglisemiye neden olabilmektedir $(3,4)$.

İnsidansının 1/100.000 olduğu tahmin edilmekle beraber etnisite ve akraba evliliklerinin görülme sıklığını arttırdığı düşünülmektedir (5).

Tip-1 Diabetes Mellitus (T1DM), mutlak insülin eksikliğinin neden olduğu hiperglisemi ile karakterize kronik bir otoimmün hastalıktır (6). Diabetes Mellitus tanısı, uyumlu semptomlarla beraber ya açlık kan glukoz düzeyinin $\geq 126 \mathrm{mg} / \mathrm{dL}$ olması ya da rastgele olarak ölçülen kan glukoz düzeyinin $\geq 200$ $\mathrm{mg} / \mathrm{dL}$ olması veya oral glukoz tolerans testinde bozukluk saptanmasıyla konulmaktadır (7). Kan glukoz regülasyonunda normal fizyolojiyi sağlayan subkutan insülin tedavisi, T1DM'de tedavinin temelini oluşturmaktadır (8). İnsülin uygulamasının yanı sıra T1DM’li tüm çocuk ve ergenlerde enerji, makro-mikro besin öğesi içeriği ve öğün aralıkları düzenlenmiş bir beslenme yönetimi de tedavi için elzemdir. Beslenme önerileri kültürel faktörler vegeleneksel yaklaşımların yanı sıra çocuğun ve ailenin bilişsel ve psikososyal koşullarına uygun olarak düzenlenmelidir. Günlük enerjinin yaklaşı \%45-50'sinin karbonhidratlardan, \%15-20'sinin proteinlerden ve \%30-35'inin yağlardan karşılanması önerilmektedir (9).

Herediter tirozinemi tip-1'li hastalarda pankreasta histopatolojik anormallikler bildirilmiş olsa da insüline bağımlı T1DM birlikteliği literatürde sınırlı sayıda tanımlanmıştır. Bu olgu sunumunda, HT1 ve T1DM birlikteliği olan olgunun beslenme yönetimi paylaşılmıştır.

\section{OLGU SUNUMU}

Güncel yaşı 12 yaş 7 ay olan kız olgu, ilk kez beş aylıkken hepatosplenomegali ve karaciğer enzimlerinde yükseklik nedeniyle başvurduğu hastanede kan tirozin ve süksinilaseton düzeylerinde yükseklik saptanarak tirozinemi tip-1 tanısı almıştır. Hastaya, fenilalanin ve tirozinden kisıtlı diyet ve nitisinon tedavileri başlanarak izleme alınmıştır. Anne-baba akrabalığı olan hastanın ailesinde benzer hastalık öyküsü bulunmamaktadır. Takiplerine düzenli olarak devam eden hasta 11 yaş 10 aylıkken poliüri, polidipsi ve kan glukoz düzeyi yüksekliği nedeniyle kliniğimize başvurmuştur. Hastada noktüri veya vücut ağırlık kaybı saptanmamıştır. Açlık kan glukozu 300 mg/ $\mathrm{dL}$ olan hasta ileri tetkik ve kan glukoz regülasyonu sağlamak amacıyla servise yatırılmıştır. Hastanın anneannesinin 68 yaşında Tip-2 Diabetes Mellitus tanısı aldığı aile tarafından beyan edilmiştir.

Başvurudaki antropometrik değerlendirmede vücut ağırlığı: $40 \mathrm{~kg}$ (-0.51 SD), boy uzunluğu: 150 cm (-0.28 SD) olarak belirlenmiş ve BKİ: $17.78 \mathrm{~kg} / \mathrm{m}^{2}$ (-0.41 SD) hesaplanmıştır (10). Sarılık, dehidrasyon bulgusu, asidotik solunum, ağızda keton kokusu, hepatosplenomegali, peteşi veya purpurası bulunmayan hastanın sistemik muayenesi normal bulunmuştur. Tanner evrelemesine göre puberte evre 4 olarak tespit edilmiştir (11). Laboratuvar incelemede; açlık kan glukoz düzeyi: $376 \mathrm{mg} / \mathrm{dL}$ (normal aralık: 70-100 mg/dL) olarak saptanmıştır. Kan gazında metabolik asidozunun olmadığı, böbrek fonksiyon testleri ve kan elektrolitlerinin normal 
sınırlarda olduğu saptanmış, ancak kan ketonu pozitif olarak ölçülmüştür. HbA 1 C \%7.7 (normal aralık: \%4-6) olarak tespit edilmiştir. Glutamik asit dekarboksilaz ve adacık hücre antikorları pozitif olan hastaya T1DM tanısı konulmuştur. Hastanın bu dönemde HT1 izlemi açısından bakılan son karaciğer enzimleri, albümin düzeyi, koagülasyonu ve plazma tirozini normal olarak ölçülmüştür. Diyabet tablosu nedeniyle istenen karın manyetik rezonans görüntülemesinde karaciğer ve pankreasın normal olduğu rapor edilmiştir. İzlemde olgunun insülin tedavisi $0.45 \mathrm{U} / \mathrm{kg}$ (\%35 bazal, \%65 bolus) olacak şekilde ayarlanmıştır ve bu tedavi ile hastanın kan glukoz düzeyleri regüle olmuştur. Hastanın tirozinemi diyeti, 3 ana 3 ara öğün şeklinde tekrar düzenlenmiştir. HT1 kaynaklı mevcut doğal protein ve tirozin kısıtlamasına ilaveten, T1DM nedeniyle karbonhidrat sınırlaması da uygulanmıştır. Diyetle alınan toplam protein 60 g/gün (1.5 g/kg/gün), fenilalanin+tirozin $680 \mathrm{mg} / \mathrm{gün}$ (17 mg/kg/gün) ve enerjinin \%55'i karbonhidrattan sağlanacak şekilde

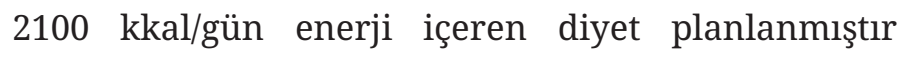
(Tablo 1). İzleminde herhangi bir sorun olmayan hasta yatışının 4. gününde taburcu edilmiştir. Kontrol laboratuvar değerlendirmede günlük kan glukoz takipleri ve $\mathrm{HbA}_{1} \mathrm{C}^{\prime}$ deki \%6'ya gerileme nedeniyle insülin dozu azaltılmıştır. İzlemde hastanın günlük besin tüketim kayıtları ile birlikte kan glukoz düzeyleri günlüğü rutin olarak değerlendirilmiştir. Diyette besin çeşitliliği sağlayabilmek için olgu ve ailesine orta düzeyde karbonhidrat sayımı eğitimi verilmiş olup ileri düzey karbonhidrat sayımı eğitimine halen devam etmektedir. Diyetteki yağ oranı \%6 arttırılmış ve karbonhidrat oranı \%9 azaltılmıştır. Tip-1 Diabetes Mellitus tanısından sonraki bir yıllık dönemde T1DM veya HT1 kaynaklı herhangi bir metabolik sorun/atak yaşanmamıştır.

\section{TARTIŞMA}

Herediter tirozinemi tip-1'e bağlı oluşan patolojik değişiklikler en çok karaciğer, böbrek ve pankreasta gözlenmektedir. Olguların \%50'sinde pankreas adacık hücre hiperplazisi olduğu görülmüştür (12). Kalıtsal tirozinemi tip-1'de, önce hipoinsülizm ve ardından
T1DM gelişimi görülebilmektedir. Hipokalemi, asidoz, hipofosfatemi ve hipermetiyonemi gibi kalıtsal tirozinemi tip-1'deki bazı biyokimyasal anormalliklerin de teorik olarak diyabet patogenezine katkıda bulundukları düşünülmektedir (13). Toksik tirozin metabolitlerinin pankreas üzerindeki etkisi klinik araştırmalarda ilgi çekici bir konu olmaya devam etmektedir.

Nitisinon, 2-(2-nitro-4-triflorometilbenzoil)-1,3sikloheksandion (NTBC), toksik tirozin ara ürünlerinin oluşumunu engelleyen farmakolojik bir ajan olup, tirozinemi hastalarında kullanılması ile sağ kalımın arttığı ve komplikasyonların azaldığı görülmüştür (3). Nitisinonun, yeterli miktarda enerji içeren tirozin ve fenilalanin kısıtlı diyetle birlikte kullanılması önerilmektedir (14).

Tirozinemi hastalarında diyet tedavisi ile plazma aminoasit konsantrasyonlarını referans aralıklarda (fenilalanin:>50 $\mu \mathrm{mol} / \mathrm{L}, \quad$ tirozin:200-400 $\mu \mathrm{mol} / \mathrm{L}$ ) tutmak için fenilalanin ve tirozin aminoasitlerini kısıtlamak ve normal büyüme, gelişmeyi desteklemek amaçlanmaktadır (15). Erken çocuklukta aile desteği ile göreceli olarak kolay uygulanan diyetin adölesan dönemde, genellikle ciddi kisitlamalar nedeniyle sorunlar yaşanmasına neden olduğu bilinmektedir. Bu nedenle hastaya ve ailesine, düzenli aralıklarla diyete uyumu artırmak için beslenme eğitimi verilmelidir (16). Olgumuz literatürün önerilerine benzer şekilde $0.5 \mathrm{mg} / \mathrm{kg} / \mathrm{gün}, 2$ dozda NTBC tedavisine ilaveten tirozin ve fenilalanin kisitlı diyet uygulamakta ve düzenli aralıklarla diyet eğitimine devam etmektedir.

Diyetle alınan doğal protein miktarı günlük gereksinimleri karşılamada yetersiz olduğundan, hastalara tirozin ve fenilalanin içermeyen aminoasit karışımları önerilmektedir. Fenilalanin ve tirozin içermeyen aminoasit karışımı ve doğal proteinin birlikte alımı, Tablo 2'de belirtilen günlük protein gereksinimini sağlamalıdır (17). Güncel yaşı 12 yaş 7 ay olan olguya diyetiyle, doğal proteine ek olarak fenilalanin ve tirozin içermeyen aminoasit karışımı ile $60 \mathrm{~g} / \mathrm{gün}$ protein sağlanmıştır. 
Tablo 1. Olgunun demografik özellikleri ve ikincil hastalık tanısı (T1DM) öncesi ve sonrası dönemde önerilen diyetin özellikleri, biyokimyasal bulguları ve medikal tedavisi

\section{Demografik Özellikler}

Yaş (yıl)

Vücut ağırlığı (kg)

Boy uzunluğu (cm)

BKI $\left(\mathrm{kg} / \mathrm{m}^{2}\right)$

Diyetle Aldığı

Enerji (kkal)

Protein (g)

Protein (enerji \%)

Karbonhidrat (g)

Karbonhidrat (enerji \%)

Yağ (g)

Yağ (enerji \%)

Fenilalanin+tirozin (mg)

Diyetle Aldığı Aminoasit Karışımları/Modüler Ürünler/Düşük Proteinli Özel Ürünler

Tirozin ve fenilalanin içermeyen aminoasit karışımı

Karbonhidrat içeren toz formula

Protein içermeyen toz formula

Düşük proteinli süt

Düşük proteinli tıbbi ekmek

Diyetle Aldığı Doğal Besinler

Tahıl değişimi*

Sebze değişimi*

Meyve değişimi*

Yağ değişimi

Mısır nişastası

Şeker

\section{Biyokimyasal bulgular}

Albumin (mg/dL)

AST (U/L)

ALT (U/L)

Tirozin (mg/dL)

Fenilalanin (mg/dL)

$\mathrm{HbA}_{1} \mathrm{c}$ (\%)

\section{Medikal tedaviler}

Nitisinon

Yoğun insülin tedavisi

$0.6 \mathrm{~g}$ protein ve bir meyve değişimi $15 \mathrm{mg}$ fenilalanin, $10 \mathrm{mg}$ tirozin ve $0.5 \mathrm{~g}$ protein içermektedir.

\section{6}

40

150

17.7

T1DM tanı öncesi

2108

60.6

11

338

61

73

28

674

$\begin{array}{cc}70 \mathrm{~g} & 70 \mathrm{~g} \\ 40 \mathrm{~g} & 40 \mathrm{~g} \\ 40 \mathrm{~g} & 50 \mathrm{~g} \\ 45 \mathrm{~g} & 20 \mathrm{~g} \\ 200 \mathrm{~g} & 200 \mathrm{~g}\end{array}$

$\begin{array}{cc}2 & 3 \\ 6 & 6 \\ 4 & 3 \\ 3 & 4 \\ 30 \mathrm{~g} & 30 \mathrm{~g} \\ 20 \mathrm{~g} & -\end{array}$

\section{9}

24

13

3.65

0.75

7.7

4.12

22

15

7.5

0.2

5.9
$0.72 \mathrm{mg} / \mathrm{kg}$ $0.45 \mathrm{U} / \mathrm{kg}$ (\%35 bazal, \%65 bolus)
Karbonhidrat içeren besinlerin ve bunların kan glukoz düzeyi üzerindeki etkilerinin bilinmesine dayalı bir yöntem olan karbonhidrat sayımı, çoklu doz insülin tedavisi veya sürekli subkutan insülin infüzyonu yoluyla bazal/bolus insülin rejimi ile tedavi edilen T1DM’li hastalar için bir öğün planlama 
Tablo 2. Herediter Tirozinemi Tip 1'de Günlük Besin Öğesi Alım Önerileri (16)

\begin{tabular}{lcccc}
\hline Yaş (yıl) & $\begin{array}{c}\text { Fenilalanin+Tirozin } \\
\text { (mg/gün) }\end{array}$ & $\begin{array}{c}\text { Toplam protein } \\
\text { (g/gün) }\end{array}$ & $\begin{array}{c}\text { Enerji } \\
\text { (kkal/gün) }\end{array}$ & $\begin{array}{c}\text { Sivl } \\
\text { (mL/gün) }\end{array}$ \\
\hline $11-15$ & $800-1200$ & $\geq 50$ & $2200(1500-3000)$ & $1500-3000$ \\
$16-19$ & $800-1200$ & $\geq 55$ & $2100(1200-3000)$ & $1200-3000$ \\
$>19$ & $800-1000$ & $\geq 60$ & $2100(1400-2500)$ & $1400-2500$ \\
\hline
\end{tabular}

aracıdır (18). Bu yöntem sayesinde, uygun şekilde eşleştirilmiş insülin-karbonhidrat oranları ve bu çerçevede yeterli düzeyde insülin uygulanması ile optimal postprandiyal glisemik kontrol olgumuzda sağlanmıştır.

Literatürde, tip 1 tirozinemi ve eşlik eden LennoxGastaut sendromlu bir hastada, fenilalanin ve tirozin kısıtll diyete uyumlu bir şekilde ketojenik diyet tedavisinin uygulandığı bildirilmiştir. Ketojenik diyet kademeli bir şekilde başlandıktan 3 gün sonra hedeflenen enerji alımına ulaşılmış ve 3-6 ay boyunca nöbetlerde >\%50'den fazla azalma sağlanmıştır. Bu durumda, düşük tirozin/fenilalanin ve kontrollü protein alımı ile birlikte ketojenik diyetin alternatif tedavi yöntemi olarak kullanılabileceği bildirilmiştir (19). Akçaağaç şurubu idrar hastalığı olan ve sonrasında T1DM tanısı alan bir olguya lösin kısıtlamasına ilaveten sık beslenme ve insülin tedavisi uygulanarak tedavisinin başarıyla sürdürüldüğü rapor edilmiştir (20). Literatürde ilk olarak 1979 yllında, poliüri, glukozüri ve hiperglisemi ile başvuran HT1'li erkek hastaya T1DM tanısı konulmuştur. Hastanın tedavisinde 12 ünite/gün insülin ve her iki hastalığın gerektirdiği şekilde düzenlenen diyet tedavisi uygulanmıştır. Tedavinin devam ettiği ilk bir yll içerisinde hastada herhangi bir metabolik bozukluk belirlenmemiştir (13). Literatür ile benzer şekilde bizim olgumuzda da sık beslenme önerisi, tirozin-fenilalanin kısıtlı diyete ilaveten yoğun insülin tedavisi uygulanmış ve hastanın izleminde herhangi metabolik atak gözlenmemiştir.

Sonuç olarak, birden fazla hastalıkta farklı makro besin ögelerinin kısıtlanması, ögün planlamada ve diyet yönetiminde zorluklara neden olabilmektedir. Bireysel özellikler göz önüne alınarak uygulanan yoğun insülin tedavisi, sık beslenme, tirozin ve fenilalaninden kisitlı diyet tedavisi ve karbonhidrat sayımı eğitimi ile bu olguda iyi metabolik kontrol sağlanmıştır. Hastalarda, tedaviye uyumu artırmak ve metabolik kontrolün sürdürülebilirliğini sağlamak amacıyla çocuk metabolizma hastalıkları ve T1DM'nin diyet tedavisinde uzmanlaşmış bir pediatri diyetisyeninin ekip içinde olması ve hastaların sürekli beslenme eğitimi ve izleminin yapılması elzemdir. Ancak bu şekilde çocuklarda eşlik eden hastalıkların medikal tedavisi ve diyet yönetiminde ögün planlama ve diyet modifikasyonları başarılı bir şekilde gerçekleştirilerek tedaviye uyum artırılabilir ve hastalıkların komplikasyon riskleri azalarak sağlık ekonomisine düşen mali yük azalabilir.

Yazarlık katkısı - Author contributions: Çalışma verilerinin elde edilmesi: TK, FDB, SÖD; Verilerin analiz edilmesi: TK, BK, CC; Makale taslağının oluşturulması: $T K, D K, E K$; İ̧erik için eleştirel gözden geçirme: BY, NÖM; Yayinlanacak versiyonun son onayl: $T K, F D B, D K, B K, C C$, EK, SÖD, BY, NÖM. - Data collection: TK, FDB, SÖD; Data analysis: TK, BK, CC; Draft preparation: TK, DK, EK; Critical review for content: $B Y, N O ̈ M$; Final approval of the version to be published: TK, $F D B, D K, B K, C C, E K, S O ̈ D, B Y, N O ̈ M$.

Çıkar çatışması - Conflict of interest: Yazarlar çıkar çatışması olmadığın beyan ederler. - The authors declare that they have no conflict of interest.

\section{Olgunun ebeveynlerinden yazılı onam alınmıştır.}

\section{KAYNAKLAR}

1. Morrow G, Angileri F, Tanguay RM. Molecular aspects of the FAH mutations involved in HT1 disease. Adv Exp Med Biol. 2017;959:25-48.

2. Couce ML, Dalmau J, del Toro M, Pintos-Morell G, AldámizEchevarría L, on Tyrosinemia type1 SWG. Tyrosinemia type 1 in Spain: Mutational analysis, treatment and long-term outcome. Pediatr Int. 2011;53(6):985-9.

3. de Laet C, Dionisi-Vici C, Leonard JV, McKiernan P, 
Mitchell G, Monti L, et al. Recommendations for the management of tyrosinaemia type 1 . Orphanet J Rare Dis. 2013;8(1):8.

4. van Ginkel WG, Jahja R, Huijbregts SCJ, Daly A, MacDonald A, De Laet C, et al. Neurocognitive outcome in tyrosinemia type 1 patients compared to healthy controls. Orphanet J Rare Dis. 2016;11(1):87.

5. Angileri F, Bergeron A, Morrow G, Lettre F, Gray G, Hutchin T, et al. Geographical and ethnic distribution of mutations of the fumarylacetoacetate hydrolase gene in hereditary tyrosinemia type 1. JIMD Rep. 2015;19:43-58.

6. DiMeglio LA, Evans-Molina C, Oram RA. Type 1 diabetes. Lancet. 2018;391(10138):2449-62.

7. American Diabetes Association. 2. Classification and Diagnosis of Diabetes: Standards of Medical Care in Diabetes. Diabetes Care. 2021;44:15-33.

8. Danne T, Phillip M, Buckingham BA, Jarosz-Chobot P, Saboo B, Urakami T, et al. ISPAD Clinical Practice Consensus Guidelines 2018: Insulin treatment in children and adolescents with diabetes. Pediatr Diabetes. 2018;19:115-35.

9. Smart CE, Annan F, Higgins LA, Jelleryd E, Lopez M, Acerini CL. ISPAD Clinical Practice Consensus Guidelines 2018: Nutritional management in children and adolescents with diabetes. Pediatr Diabetes. 2018;19:136-54.

10. Neyzi O, Günöz H, Furman A, Bundak R, Gökçay G, Darendeliler F, et al. Weight, height, head circumference and body mass index references for Turkish children. Cocuk Sagligi ve Hast Derg. 2008;51(1):1-14.

11. Marshall WA, Tanner JM.Variations in pattern of pubertal changes in girls. Arch Dis. 1969;44(235):291303.
12. Editorials. Hereditary tyrosinemia. JAMA. 1968;203(12):1062.

13. Lindberg T, Nilsson KO, Jeppsson JO. Hereditary tyrosinaemia and diabetes mellitus. Acta Paediatr. 1979;68(5):619-20.

14. McKiernan PJ. Nitisinone in the treatment of hereditary tyrosinaemia type 1. Drugs. 2006;66(6):743-50.

15. van Ginkel WG, Rodenburg IL, Harding CO, Hollak CEM, Heiner-Fokkema MR, van Spronsen FJ. Longterm outcomes and practical considerations in the pharmacological management of tyrosinemia type 1 . Pediatr Drugs. 2019;21(6):413-26.

16. van Spronsen FJ, van Rijn M, Meyer U, Das AM. Dietary considerations in tyrosinemia type I. Adv Exp Med Biol. 2017;959:197-204.

17. Acosta PB, Michals Matolan K. Nutrition management of patients with inherited disorders of aromatic amino acid metabolism. In: Acosta PB, editor. Nutrition management of patients with inherited metabolic disorders. Jones and Bartlett Publishers; 2010:119-74.

18. Tascini G, Berioli M, Cerquiglini L, Santi E, Mancini G, Rogari F, et al. Carbohydrate counting in children and adolescents with type 1 diabetes. Nutrients. 2018;10(1):109.

19. De Lucia S, Pichard S, Ilea A, Greneche M-O, François L, Delanoë C, et al. An unfortunate challenge: Ketogenic diet for the treatment of Lennox-Gastaut syndrome in tyrosinemia type 1. Eur J Paediatr Neurol. 2016;20(4):6747.

20. Gündüz M, Koç N, Ünal Ö, Uçaktürk SA. Dietary management of a patient with both maple syrup urine disease and type 1 diabetes. J Pediatr Res. 2018;21:44-6. 